\title{
Seyyed Hossein Nasr's Teaching on Sufism and Its Relevance to Modern Society
}

\author{
Amir Maliki Abitolkha \\ Universitas Islam Negeri Sunan Ampel Surabaya - Indonesia \\ Email: amir.abitolkha@gmail.com
}

\begin{abstract}
This article examines Seyyed Hossein Nasr's teaching on Sufism and its relevance to modern society. The fact is that the paradigm and lifestyle of modern humans are materialism-oriented. Therefore, they experience a spiritual emptiness that causes anxiety. This study applies the literature approach by collecting various related sources. This study found that Seyyed Hossein Nasr's idea of neo-Sufism can be an alternative paradigm for modern people to free themselves from the threat of materialism and hedonism. The Divine spirit of humans will form spiritual power in the human soul to keep the connectivity between the servant and God. Nasr's teaching on Sufism puts forward the concept of balance and moderation between the life in this world and hereafter, between shari'ah and haqeqat, and between individual and social life.
\end{abstract}

Keywords: Seyyed Hossein Nasr, Sufism teaching, Moral, Social, Spiritual, Modern Society

\section{A. Introduction}

Sufism has become an "icon" for modern society in the $21^{\text {st }}$ century, which is now being suppressed by the complex problems of life. Sufism is needed as it offers spiritual tranquillity, which could calm one's psychological condition that is an inner peace that has become a "dream" of all people to be able to enjoy life normally. ${ }^{1}$ The assumptions of having positions, wealth, careers, luxurious homes, and good vehicles that can make a person happy and peaceful are now starting to fade. The people now begin to find inner improvement, obedience, spiritual purification and begin to develop closeness to God because it would bring them to a meaningful life and happiness. ${ }^{2}$

${ }^{1}$ Aminudin, "Urgensi Tasawuf Dalam Membangkitkan Kesadaran Spiritual Bagi Masyarakat Modern," Farabi 17.2 (2020): 91-104.

2 Lina Nurhasanah, "Peran Tasawuf dalam Kehidupan Manusia Modern (Perspektif Sayyed Hossein Nasr)," El-Afkar: Jurnal Pemikiran Keislaman dan Tafsir Hadis 6.2 (2017). 
The teaching of Sufism functions as a step to educate modern society to get inner enlightenment and free from the constraints of worldly life and lust. ${ }^{3}$ The teaching does not focus on the theoretical aspect but more practical by connecting the aspects of shari'ah, tareqat, haqiqat to makrifat; connecting physical and mental aspects to feel the essence of worship perfectly. ${ }^{4}$ The teachings of Sufism comprises zikir (remembrance of Allah) solemnly and continuously, fasting, upholding sunnah (recommended) worship, munajat in the middle of the night, riyadhah, mujahada to be robust against the lust temptation, till the stage of tazkiyat an-nafs (soul purification) to be able to achieve the degree of "qalbun salim",5 which is then supported by the implementation of zuhud, qanaah, tawakkal, sincere, patient, happy and other praiseworthy attitudes. ${ }^{6}$ There is also the teaching which is practiced in the form of tareqat (Sufi order) where students are nurtured by a Sufi teacher called murshid. ${ }^{7}$ Such a model of teaching in Sufism is known as Tasawufamali (practice-based Tasawuf). ${ }^{8}$

Seyyed Hossein Nasr presents the face of Sufism not in an inclusive and extreme position, but rather a hamble, humanist, moderate, and proportionate that is more sociable. It aims to lead people to a balanced and fair life journey. ${ }^{9} \mathrm{~A}$ social character must be built to create a dimension of harmony in life among

\footnotetext{
${ }^{3}$ Rahabistara Bistara, "Tariqah Dimensi Esoteris Dalam Islam (Studi Pemikiran Sayyed Hossein Nasr)." Journal of Islamic Civilization 2.2 (2020): 72-79. Andi Eka Putra, "Tasawuf Sebagai Terapi Atas Problem Spiritual Masyarakat Modern," Al-Adyan:Jurnal Studi Lintas Agama 8.1 (2013): 45-57.

4 Syamsun Ni'am, "Institusi Pendidikan Dalam Tasawuf," Kanz Philosophia A Journal for Islamic Philosophy and Mysticism 3.2 (2013): 185-200. Ibnu Ali, "Nilai-Nilai Dasar Pendidikan Tasawuf Dalam Paradigma Mistik Ibnu 'Arabi Tentang Insan Kamil," El-Furqania: Jurnal Ushuluddin Dan Ilmu-Ilmu Keislaman 3.01 (2017): 16-37.

5 Ali Mustofa, "Pendidikan Tasawuf Solusi Pembentukan Kecerdasan Spiritual dan Karakter," Inovatif: Jurnal Penelitian Pendidikan, Agama dan Kebudayaan 4.1 (2018): 111-139.

6 M. Ihsan Dacholfany, "Pendidikan Tasawuf di Pondok Modern darussalam Gontor." Nizham Journal of Islamic Studies 3.2 (2015): 27-42. Jauhar Fuad, "Pendidikan Karakter Dalam Pesantren Tasawuf," Tribakti: Jurnal Pemikiran Keislaman 23.1 (2012). Siti Maryam. Munjiat, "Peran Tasawuf Dalam Pendidikan Karakter," Al-Tarbawi Al-Haditsah: Jurnal Pendidikan Islam 3.2 (2018).

${ }^{7}$ Agus Sholikhin, "Tarekat Sebagai Sistem Pendidikan Tasawuf," Conciencia 18.2 (2018): 1-13.

8 Rifyal Luthfi MR, and Gunawan Anjar. "Konsep Pendidikan Tasawuf Amali menurut Syaikh Utsman ibn Hasan ibn Ahmad Syakir Al-Khaubawi dalam Kitab Durrah An-Nasihin dan Implementasinya dalam Pembelajaran PAI," Journal Civics \& Social Studies 3.2 (2019): 53-59.

9 A. Gani. "Pendidikan Tasawuf Dalam Pembentukan Kecerdasan Spiritual Dan Akhlakul Karimah." Al-Tadzkiyyah: Jurnal Pendidikan Islam 10.2 (2019): 275-286.
} 
people. Seyyed Hossein Nasr uses this approach in indoctrinating the spirits of Sufism amid society, considering that Sufism for the modern society cannot be designed with the classical approach, meaning that it must be able to adapt to the times so that it can be accepted and practiced by the community. ${ }^{10}$

The teaching of Sufism, according to Seyyed Hossein Nasr, must synergize the moral, spiritual, and social aspects of society, so that its orientation is not only limited to the spiritual aspect. Given that, Sufism does not only focus on spiritual formation between servants and God but more than that, presenting Allah in every action by constantly internalizing the attributes of Allah in their daily life ${ }^{11}$ so that what they say, behave, think about not going away from His names (asma), which will cultivate nobility. ${ }^{12}$ The intellect nobility and sharpness of the inner atmosphere will be led to a complete social sensitivity as a representation of their responsibilities as social beings. ${ }^{13}$ The meeting point between these three aspects is the goal of Seyyed Hossein Nasr's teaching of Sufism. ${ }^{14}$

Nasr tries to make the face of Sufism more humble so that people can accept and learn it, entering into the world of Sufism with a more flexible understanding. Therefore Sufism cannot only be understood textually like the classical times but it must be applied contextually to answer the challenges and needs of today's society. 15 The $21^{\text {st }}$ century is a time when the information-technology developed so fast. Sciences are growing significantly and affect the pattern of life as well as the perspective of this century's society. The progress that has been achieved by modern humans this time also brings problems that plague their minds and

10 Sofyan Rofi., Benny Prasetiya, and Bahar Agus Setiawan. "Pendidikan Karakter Dengan Pendekatan Tasawuf Modern Hamka dan Transformatif Kontemporer," Intiqad: Jurnal Agama dan Pendidikan Islam 11.2 (2019): 396-414. Andi Eka Putra, "Tasawuf Sebagai Terapi Atas Problem Spiritual Masyarakat Modern,": 45-57.

11 Muhammad Husnur Rofiq, and Prastio Surya. "Model Pembentukan Karakter Berbasis Tasawuf Akhlaqi," Ilmuna: Jurnal Studi Pendidikan Agama Islam 1.2 (2019): 65-81.

12 Restu Andrian, "Modernisasi Tasawuf Dalam Pengembangan Pendidikan Karakter," Jurnal Mudarrisuna: Media Kajian Pendidikan Agama Islam 9.1 (2019): 36-50.

13 Lukman, "Tasawuf Dalam Perspektif Sayyed Hossein Nasr," El-Afkar: Jurnal Pemikiran Keislaman dan Tafsir Hadis 8.2 (2019): 25-36.

14 Nadhif Muhammad Mumtaz, "Hakikat Pemikiran Seyyed Hossein Nasr," Jurnal IndoIslamika 4.2 (2014): 169-178.

15 Jaipuri Harahap, "Sayyed Hossein Nasr Tentang Filsafat Perennial Dan Human Spiritualitas," Aqlania: Jurnal Filsafat dan Teologi Islam 8.2 (2017): 73-96.

JURNAL THEOLOGIA - Volume 32, No. 1, Juni 2021 
psyche as a result of a wrong paradigm that violates the foundations of religion. Besides, people's lifestyle tends towards pleasure, materialism, and worldliness that neglect the interests of life of the hereafter. ${ }^{16}$

Sufism education was born to pull modern society from the "hole" of sorrow to the "maqam" of the muttaqin and muhsinin, purify humans from a state of humiliation to become holy again before facing the Most Holy substance. ${ }^{17}$ Sufism itself is a path to the sanctity of the soul and heart prepared to meet Allah, ${ }^{18}$ because, with a pure soul, a servant can approach Him without a barrier (hijab). ${ }^{19}$ The aridity of the human mind begins with the dirtiness of the soul and heart, which make them far away, even forgetting the existence of God and their essence as created beings. ${ }^{20}$

The other studies on Nasr are dealing with the role of universal Sufism, ${ }^{21}$ the concept of Sufism in the modern age, ${ }^{22}$ divine philosophy, ${ }^{23}$ humanism and art in Islamic education, ${ }^{24}$ spiritual power, ${ }^{25}$ and human dimension. ${ }^{26}$ While his concept of Sufism education seems to have not been studied so far. For this reason,

${ }_{16}$ M. Mahdi Alatas, "Spiritualitas Dan Modernitas MenurutPemikiran Seyyed Hossen Nasr (Studi Atas Agama Dan Krisis Kemanusiaan Modern)," Jurnal Akrab Juara 5.2 (2020): 147-160.

17 Maisyaroh, "Tasawuf Sebagai Dimensi Batin Ajaran Islam," At-Tafkir 12.2 (2019): 141-151.

18 Mohammad Arista, "Relevansi Ajaran Budha Dan Tasawuf." Putih Jurnal Pengetahuan Tentang Ilmu Dan Hikmah 2.1 (2017): 65-100. Zaki Hidayatulloh, "Pemahaman Islam Melalui Pendekatan Tasawuf," At-Tahdzib: Jurnal Studi Islam dan Muamalah 2.1 (2014): 65-81.

19 Umar Faruq Thohir, "Tasawuf Sebagai Solusi Bagi Problematika Kemodernan: Studi Pemikiran Tasawuf M. Amin Syukur," Jurnal Theologia 24.2 (2013): 43-68.

20 Azaki Khoirudin, "Rekonstruksi Metafisika Seyyed Hossein Nasr dan Pendidikan Spiritual," Afkaruna: Indonesian Interdisciplinary Journal of Islamic Studies 10.2 (2014): 202-216.

21 Dedy Irawan, "Tasawuf Sebagai Solusi Krisis Manusia Modern: Analisis Pemikiran Seyyed Hossein Nasr," Jurnal Tasfiyah: Jurnal Pemikiran Islam 3.1 (2019).

22 Lukman. "Tasawuf Dalam Perspektif Sayyed Hossein Nasr," El-Afkar: Jurnal Pemikiran Keislaman dan Tafsir Hadis 8.2 (2019): 25-36.

23 Fathin Fauhatun, "Islam dan Filsafat Perenial: Respon Seyyed Hossein NasrTerhadap Nestapa Manusia Modern," Jurnal Fuaduna: Jurnal Kajian Keagamaan dan Kemasyarakatan 4.1 (2020): 54-69.

24 Titin Nurhidayati, "Pemikiran Seyyed Hossein Nasr: Konsep Keindahan dan Seni Islami dalam Dunia Pendidikan Islam." Falasifa: Jurnal Studi Keislaman 10.1 (2019): 27-44. Zaki Hidayatulloh, "Islam dan Humanisme menurut Seyyed Hossein Nasr," (Tesis: Pascasarjana UIN Sumatera Utara, 2012).

25 Azaki Khoirudin, "Rekonstruksi Metafisika Seyyed Hossein Nasr dan Pendidikan Spiritual," Afkaruna: Indonesian Interdisciplinary Journal of Islamic Studies 10.2 (2014): 202-216.

${ }^{26}$ Anis Lutfi Masykur, "Manusia MenurutSeyyed Hossein Nasr,” (Skripsi: UIN Syarif Hidayatullah Jakarta-Fakultas Ushuluddin dan Filsafat, 2017). 
this study attempts to analyze Nasr's idea about the concept of Sufism education which can be an alternative way for the moral education, spiritual, social life of modern society in the 21st century. The concept of Sufism education can indeed be a solution amidst the abundance of inner and social problems of society in general $^{27}$ as a result of secularism, liberalism, hedonism, materialism, and individualism which are substantially "deviating" from the Islamic spirits. ${ }^{28}$ Therefore, Sufism education must be a "liberator" of society from these restraints. ${ }^{29}$

\section{B. Research Methodology}

This paper is a literature-based study of various documents, including books, articles, notes, reports, and other related literature. The data were obtained by processing various documents and then analyzed using a deduction, induction, and in-depth interpretation approach so that Seyyed Hossein Nasr's thought can be described and found, especially concerning his idea on Sufism education and its relevance to the moral, spiritual, and social aspects of modern society.

\section{Discussion and Results}

Seyyed Hossein Nasr was born on April 17, 1933, in Teheran, Iran, and belongs to Ahl Bayt family. His mother was educated in a family of the ulama. His father, Sayyed Waliyullah Nasser, was a doctor and educator ${ }^{30}$ during the Qajar

27 Moh. Saefulloh, "Tasawuf sebagai Solusi Alternatif dalam Problematika Modernitas," Islamica: Jurnal Studi Keislaman 2.2 (2008): 207-216.

28 M. Zainul Hasani Syarif, Pendidikan Islam dan Moralitas Sosial: Upaya Preventif-Kuratif Dekadensi Moral dan Kehampaan Spiritual Manusia Modernis. Prenada Media, 2020. Sutoyo, Sutoyo. "Tasawuf Hamka dan rekonstruksi spiritualitas manusia modern." Islamica:Jurnal Studi Keislaman 10.1 (2015): 108-136.

${ }^{29}$ Nur Cholis, and Syahril Syahril, "Konsep Tasawuf Sebagai Psikoterapi Bagi Problematika Masyarakat Modern (Study Terhadap Kitab Ihya' 'Ulumiddin Karya Imam Al-Ghazali)." Manthiq 3.1 (2018). Muhamad Basyrul Muvid, and Akhmad Fikri Haykal. "Tasawuf Humanistik dan Relevansinya terhadap Kehidupan Sosial Spiritual Masyarakat Post Modern Abad Global (Telaah Atas Pemikiran Tasawuf Said Aqil Siradj dan Muh. Amin Syukur)." Refleksi 19.1 (2020). Ali Imron, "Tasawuf dan Problem Psikologi Modern," Tribakti: Jurnal Pemikiran Keislaman 29.1 (2018): 23-35. Achmad Husen, et al. "Pendidikan Karakter Berbasis Spiritualisme Islam (Tasawuf," Jurnal Studi Al-Qur'an 10.1 (2014): 1-19.

30 Jane I. Smith, "Seyyed Hossein Nasr" dalam John L. Esposito (ed), The Oxford Encyclopedia of The Modern Islamic World (New York: Oxford University Press, 1995), Vol. 3, 230. 
dynasty who was appointed as a ministerial-level official during the Reza Pahlavi era. ${ }^{31}$ Iran itself is a country (region) that adheres to the Sufistic Shi'a tradition and has a continuous history of Islamic thought that still develops until now. Islamic thought or precisely Islamic philosophy did not die (jumud; static) with the attack of Imam al Ghazali. ${ }^{32}$

Seyyed Hossein Nasr's idea on moderate Sufism, which he calls neo-Sufism (modern Sufism), originated from the phenomenon of modern (human) society. They have lost their vision of divinity and have a void of spiritual values because they are not aware of their position as a pontifex, namely as a bridge between heaven and earth. Modern humans suffer from amnesia, forgetfulness, and neglect because of their rebellion against heavenly realities. ${ }^{33}$ As a result, they fall into a spiritual emptiness or void so that they easily damage nature without realizing that environmental pollution results from the pollution of the soul produced by them. Modern humans essentially try to live on bread alone, "kill God," and claim independence from the afterlife. ${ }^{34}$

Such condition makes human life tortured with anxiety, leading to disharmony in one's own life. ${ }^{35}$ It proves that the spiritual aspect of the human soul cannot be considered insignificant, and religion is regarded as an obstacle to human development. The human element consists of a spirit and a body, which symbolizes that humans are spiritual beings other than social beings. ${ }^{36}$

Western humanism can not be separated from this problem. It was born from an environment that is free from perfect norms so that it also falls into decadence. It does not integrate humans into noble values but instead falls into decline. To overcome these problems and bridge inner struggle to not fall into the 80.

${ }^{31}$ Abdul Aziz Dahlan (ed), Suplemen Ensiklopedia Islam (Jakarta: Ichtiar Baru Van Hoeve, 1996),

32 Fazlur Rahman, Islam, terj. Ahsin Mohammad (Bandung: Pustaka, 1994), 80.

33 Moh. Anas, "Kritik Hossein Nasr Atas Problem Sains dan Modernitas," Kalam 6.1 (2012): 2137.

34 Waryono Abdul Ghafur, et.al, Pemikiran Islam Kontemporer (Yogyakarta: Jendela, 2003), 391.

35 Mahdi. "Urgensi Akhlak Tasawuf dalam Kehidupan Masyarakat Modern." Edueksos: Jurnal Pendidikan Sosial \& Ekonomi 1.1 (2016).

36 Rakhmawati. "Sumbangsih Islam Dalam Menanggulangi Kehampaan Spiritual Masyarakat Modern; Telaah Atas Pemikiran Tasawuf Sayed Husein Nasr." Farabi 11.1 (2014): 66-82. 
hole of spiritual emptiness, Nasr offers a solution known as positive Sufism or new Sufism (neo-Sufism). ${ }^{37}$

This concept offers that a spiritual aspect must be developed wisely to be able to communicate with God and connect with Him, which will make the body calm and happy. ${ }^{38}$ Because, in fact, wealth with all its luxuries cannot make humans peaceful. Instead, it becomes a problem in life. ${ }^{39}$ The assumption of modern society has now "collapsed," so they are eager to find a spiritual way to calm their soul. ${ }^{40}$

Nasr offers neo-Sufism to modern society as recently there was a wave in which the West like to study Sufism. ${ }^{41}$ Sufism's metaphysical and mystical Islamic teachings can answer intellectual needs and satisfy humans' desire to look for God. ${ }^{42}$ Also, Sufism can give colours to lives in several fields of life, such as art, science, literature, and education. Among the contributions of Sufism in human life is to restore the true character of human beings that have been lost due to evolutionary understanding that has made humans being separated from their spiritual nature. It becomes crucial, considering that humans have both physical (outward) and spiritual (inner; psychological) aspects. This internal aspect, the soul, must continue to be trained to receive divine spiritual light to obtain perfection as a step towards reality (haqiqat). ${ }^{43}$

Moderate Sufism developed by Nasr attempts to keep humans away from the wave of moral, social, and spiritual crises due to lifestyle and wrong

37 Ibid., 391.

38 Suparman Syukur Encung, and Ilyas Supena. "Insān Kāmil In The Religious Existentialism Philosophy Of Seyyed Hossein Nasr," Hikmatuna 6.1 (2020): 40-50.

39 Irfan Noor, "Sufisme Seyyed Hossein Nasr dan Formalisme Agama Di Indonesia," Al-Banjari: Jurnal Ilmiah Ilmu-Ilmu Keislaman 13.2 (2015).

40 Masduki, "Humanisme Sekuler Versus Humanisme Religius (Kajian Tentang Landasan Filosofis dan Upaya Menemukan Alternatif Melalui Pemikiran Seyyed Hossein Nasr)." Toleransi: Media Ilmiah Komunikasi Umat Beragama 3.1 (2011): 98-118.

41 Seyyed Hossein Nasr, Tasawuf Dulu dan Sekarang, terj. Abdul Hadi WM Oakarta: Pustaka Firdaus, 1994), 2.

42 Seyyed Hossein Nasr, Islam dan Nestapa Manusia Modern, terj. Anas Mahyuddin (Bandung: Pustaka, 1983), 78.

43 Muhammad Ilham Usman, "Sufisme dan Neo-Sufisme dalam Pusaran Cendikiawan Muslim," Tahdis: Jurnal Kajian Ilmu Al-Hadis 6.2 (2019).

JURNAL THEOLOGIA — Volume 32, No. 1, Juni 2021 
paradigms. Sufism is seen as an alternative to educating humans towards true nature so that they can save from the worldly hustle and bustle. Nasr argues that humans will become failed creatures when they break away from their God, releasing their spiritual elements.44 Such kind of human will become a "wild" creature breaking through the walls of the Shari'ah, which later makes him lose and suffer in the future.

This phenomenon occurs mainly in the modern age for various reasons, but the main reason is that humans cannot adapt well to the progress and changes of the times. As a result, they are easily "blown" by time and worldly matters. They do not realize that this can erode their faith, making them far away and even inundated. They start to aware when they have experienced a spiritual and psychological crisis and thirst. In this state, they begin to look back to God to heal anxiety, restlessness, and inner loneliness. ${ }^{45}$

In Nasr's view, Sufism is based on "neo-Sufism," which indeed prioritizes aspects of balance, modernity, justice, proportion, and wisdom. It is not the face of inclusive Sufism that separates itself from worldly affairs. For this reason, neoSufism gave birth to a moderate Sufistic education pattern (wasathiyah) by applying the element of balance in life. Modern society will be guided to become a people e who are balanced between worldly affairs and the hereafter, between shari'ah and nature, between relationships with God and relationships with humans and nature, between personal and social interests, between servants and His representatives on earth, not becoming a people who transcend the limit, also not being a backward people. 46

Nasr's Sufism education with an "interconnection," approach is a meeting point between the ilahiyyah, insaniyyah and amiyyah aspects. So, a human is supposed not to concern with vertical relationships but also horizontal ones. ${ }^{47}$

44 Muhammad Sakdullah, "Tasawuf di Era Modrnitas (Kajian Komprehensif Seputar NeoSufisme)," Living Islam:Journal of Islamic Discourses 3.2 (2020): 364-386.

45 Muhammad Bakri, "Neo-Sufisme Sebagai Alternatif Dalam Mengatasi Krisis Spritual Modern (Studi Sayeed Hossein)”. (Skripsi: Universitas Islam Negeri Sultan Syarif Kasim Riau, 2021).

46 Muhamad Basyrul Muvid, Tasawuf Kontemporer (Jakarta: Amzah, 2020), 35 \& 69. Alaika, Alaika M. Bagus Kurnia PS, Muhamad Basyrul Muvid, and Risma Savhira DL. "Sufisme Mahasiswa: Wawasan Kebangsaan Inklusif Berbasis Tasawuf." al-Afkar, Journal For Islamic Studies 4.1 (2021): 123140.

${ }^{47}$ Nesia Mu'asyara, "Humanisme dalam Perspektif Tasawuf," (Tesis: UIN Raden Intan Lampung, 2019). http://repository.radenintan.ac.id/7603/ 
Thus, the essence of human duties as servants of Allah and His representatives can be carried out properly. Nasr's Sufism education does not limit human movement to only ruhaniyyah wal amaliyyah, but more than that, the dimensions of Sufism that are built do not violate aspects of the shari'ah that Allah has prescribed, especially regarding human tasks and functions. ${ }^{48}$

The position of humans is not limited to servants of God who spend their daily time worshiping and $d h i k r$, butcarrying out many actions, humane activities, and actively protecting nature from various damage. ${ }^{49}$ Nasr does not want Sufism to only lead humans to the spiritual path, especially to the concept of "jumud" which will create an unhealthy psyche. But more than that, he tried to humanize Sufistic concepts to the joints of human life and their duties and responsibilities as God's creation. Therefore, in this case, we can see how the dimensions of Sufism education of Seyyed Hossein Nasr offer to the moral, spiritual and social life of modern society. ${ }^{50}$ It is very relevant to form harmonization between morality, spirituality, and sociality of modern society.

In addition, Sufism is the universal aspect of the Islamic tradition and is the pinnacle of the spiritual essence of Islam. Therefore, Sufism is like the soul that animates the body. It is the source of life that governs all religious organisms in Islam..$^{51}$ Sufism has legal (legitimate) foundations derived from the Qur'an and Sunnah. The legality of Sufism became the basis for Nasr to be developed and formed into an educational tool to make a better human being according to his nature. Returning a man to his true identity is certainly not easy. It requires a spiritual-based humane approach to touch his soul so that awareness grows to return to the divine path. ${ }^{52}$ Thus, Sufism education is very necessary to be applied as a "bridge" between humans and their God.

48 Sulaiman, "Perubahan Sosial Berbasis Tasawuf: Studi Kasus Fethullah Gülen Dan Gülen Movement," Al-Tahrir: Jurnal Pemikiran Islam 16.1 (2016): 21-46.

${ }^{49}$ Suwito, "Etika Lingkungan dalam Kosmologi Sufistik Menurut Seyyed Hossein Nasr," Madania: Jurnal Kajian Keislaman 21.2 (2017): 221-234.

50 Akhmad Sukardi, "Dakwah Islam Melalui Ajaran Tasawuf," Al-Munzir 8.1 (2018): 1-14.

${ }^{51}$ Seyyed Hossein Nasr, Ideals and Realities of Islam (London: George Allen \& Unwin LTD, 1968), 121.

52 Hasan, Ismail. "Tasawuf: Jalan Rumpil Menuju Tuhan." An-Nuha: Jurnal Kajian Islam, Pendidikan, Budaya Dan Sosial 1.1 (2014): 45-63.

JURNAL THEOLOGIA — Volume 32, No. 1, Juni 2021 
Then, according to Nasr, Sufism gradually would extinguish lust and becomes the real self. So, a Sufi is a person who throws away a character, a lousy character (akhlak al madzmumah) like a snake that sheds its skin.53 This is done by constantly feeling the presence of Allah in the heart (hudlur al qalb ila Allah), breaking away from the entanglements of the world (its glitter and luxury), and not being satisfied with the material. A Sufi is a person who is aware that the essential thing of his existence is to make a spiritual journey (rihlah) that is from the outward to the inner, ${ }^{54}$ from the sphere of his living to the transcendent center. ${ }^{55}$ This view is related to the theory of the rim and axis which states that the nature of the world consists of two aspects, namely adz dzahir (physical, outward) and al batin (inner, spiritual, inward). ${ }^{56}$

Nasr's view of neo-Sufism shows that Sufism emphasizes the psychological aspect, not the physical. Therefore, the soul that is at the psychic level must be organized, trained and disciplined. ${ }^{57}$ It confirms that Sufism is a means of attaining the sanctity of the soul and a medium for encountering Allah. People who want to go through this spiritual realization must necessarily undergo the practice of Sufism except carrying out the orders of shari'ah (fiqh).58

Regarding the doctrine, Sufism is an Islamic tradition based on monotheism so that all its manifestations always reflectmonotheism (wholeness and oneness). That is, all methods and practices always lead to unity or to unite separate things. Islamic Sufism in this regard, neo-Sufism (moderate Sufism), never separates the life of contemplation (isolation) and social activities. ${ }^{59}$ According to Nasr, contemplation in its traditional sense is always combined with the notion of action, 60 in accordance with the statement that God's action is related to His contemplation.

53 Hossein Nasr, TasawufDulu., 4.

54 Ahmad Sidqi, "Wajah Tasawuf di Era Modern: antara Tantangan dan Jawaban," Epistemé: Jurnal Pengembangan Ilmu Keislaman 10.1 (2015): 1-28.

55 Ibid., 8.

56 Waryono Abdul Ghafur, et.al, Pemikiran Islam...., 393.

${ }^{57}$ Seyyed Hossein Nasr, Islam dan Nestapa., 87.

58 Seyyed Hossein Nasr, Islam Tradisi di Tengah Kancah Dunia Modernisme, terj. Luqman Hakim (Bandung: Pustaka, 1987), 5.

59 Mahdi. "Konteks Doktrinal Akhlak TasawufDalam Realitas Sosial." Edueksos: Jurnal Pendidikan Sosial \& Ekonomi 2.2 (2016).

60 Ibid., 112. 
The doctrine of inseparability gets a normative basis both from the Qur'an and history. According to Nasr, in the history of Islam, many Sufi figures are known as scholars, artists, teachers, and even as officials. ${ }^{61}$ The most representative and valid model is the Prophet himself. A Messenger is a human typology that re-harmonizes the contemplative life with the life of action. ${ }^{62}$ Therefore, it is wrong if Sufism is considered to have led to a static life and stagnancy (jumud). A Sufi does not necessarily have to leave the 'stage' of the real world, both related to humans and other creatures. A Sufi outwardly still participates in society (mu'amalah; ijtima'iyah). ${ }^{63}$ Islamic Sufism emphasizes deep esoteric religious appreciation without exile or 'uzlah. Neosufism emphasizes activity, real movement, responsiveness, reactiveness and does not isolate himself from society. ${ }^{64}$

For Nasr, humans are responsible to themselves, God, creatures (fellows), and nature (environment). ${ }^{65}$ Humans are not only divine beings ('abdun), but also social beings (khalifat fi al-Ardl), ${ }^{66}$ so it is not true that humans are only concentrated on one aspect. Everything must be balanced and work well. This is the essence of the teachings of Islam that are practiced by the real Sufis, which are packaged in neo-sufism (moderate Sufism). ${ }^{67}$

With this concept of Sufism, Nasr has laid the foundations for the teachings of neo-Sufism or positive Sufism. ${ }^{68}$ The integration between the two aspects, namely physical and spiritual, is the hallmark of Islamic Sufism and according to

61 Ibid., 119

62 Ibid., 126.

63 Ibid., 97.

${ }^{64}$ Azyumardi Azra, "Neo-Sufisme dan Masa Depannya" dalam Muhammad Wahyuni Nafis (ed), Rekontruksi dan Renungan Religius Islam (Jakarta: Paramadina, 1996), 295.

65 Seyyed Hossein Nasr, The Heart of Islam, terj. Nurasiah Fakih Sutan Harap (Bandung: Mizan, 2003), 339-340.

66 Ida Munfarida, "Relevansi Nilai-Nilai Tasawuf bagi Pengembangan Etika Lingkungan Hidup," Indonesian Journal of Islamic Theology and Philosophy 2.1 (2020): 19-40.

${ }^{67}$ Barsihannor Annur, "Sayyed Hossein Nasr (Sufisme Masyarakat Modern)," Al-Hikmah Journal for Religious Studies 15.2 (2014): 127-134.

${ }^{68}$ Nurcholis Majid, "Sufisme Baru dan Sufisme Lama: Masalah kontuinitas dan Perkembangan dalam Esoteris Islam" dalam Djohan Effendi (penyunting), Sufisme dan Masa Depan Agama (Jakarta: Pustaka Firdaus, 1993), 93. 
the true teachings of Islam. Therefore, for Nasr, living the shari'ah (outwardly) without the tariqah is impossible. Vice versa, the relationship between the two is like a walnut whose skin resembles shari'ah, its fruit is like tariqah, and the oil, which is invisible but can be felt is the essence. Walnuts withoutskin will not grow in the natural world and without the fruit also have no meaning. Likewise, shari'ah without tariqah will not have an outward form and will not be able to survive and manifest itself in the world. ${ }^{69}$ As Imam Malik said: ${ }^{70}$

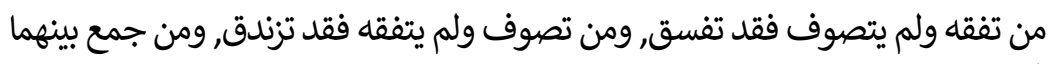

Sufism initiated by Seyyed Hossein Nasr is far from a negative image, i.e., Sufism that ignores shari'ah, antinomian, eclectic, excessive, or extravagant.71 Reconciliation and compromise between shari'ah and Sufism are what is called Neo-Sufism. After humans experience union with Allah, what remains is only one reality or unity of being (wahdah al-wujud). This doctrine, which is not identical with pantheism or panentheism, is the last station in the process of a human spiritual journey which is a direct consequence of the shahadat (tawhid). ${ }^{72}$ However, Nasr said that this is not the ultimate goal of the spiritual journey because the most important thing here is to reach insan kamil (universal human), namely, a human who does not only think (an nathiq), but also a human who has various levels of existence, so that he is able to become a mirror of names (asma') and His noble attributes. ${ }^{73}$

For Nasr, that is the goal of Sufism, namely to form a complete and holy human being in which the universal personality is included. ${ }^{74}$ And herein lies the difference with Nietzsche's concept of insan kamil. In Nietzsche, humans reach that level by 'killing God,' whereas Nasr brings Him to life. ${ }^{75}$

${ }^{69}$ Nasr, Ideals and Realities of Islam., 124.

70 Ibid., 125.

${ }^{71}$ Azyumardi Azra, "Neo-Sufisme dan Masa Depannya" dalam Muhammad Wahyuni Nafis (ed), Rekontruksi dan Renungan Religius Islam (Jakarta: Paramadina, 1996), 289.

72 Nasr, Ideal and Realities., 137.

73 Ibid., 138.

${ }^{74}$ Nasr, TasawufDulu., 43-44.

75Waryono Abdul Ghafur, et.al, Pemikiran Islam., 396. 
Nasr, with his Sufism, not only wants to 'marry' or re-synergize Sufism with sharia, more than that, to look positively at the phenomenon of religious diversity. We can examine this from two sides. First, related to the universal understanding of Sufism, it is both perennial and universal at the same time. ${ }^{76}$ Secondly, it relates to the nature of neo-Sufism, namely its emphasis on pluralism. ${ }^{77}$ At this last level, Nasr still emphasizes the importance of shari'ah and other formal worship such as prayer, fasting, zakat and others, between esoteric and exoteric, ${ }^{78}$ between tasawuf and shari'ah. Even though they can be distinguished, they cannot be separated. 79

Nasr's Sufism illustrates that the seeker (salik) of Sufism does not have to separate himself from society, passive and pessimistic, and totally surrender without effort. Rather, it makes the salik active, proactive, and dynamic in undergoing life in this world for the preparation of the hereafter. ${ }^{80}$ Spiritual values become the power to grow social values for the benefit of himself personally and also for others towards a proportional life between the world and the hereafter. ${ }^{81}$

\section{Conclusion}

Seyyed Hossein Nasr's teaching on Sufism suggests that people are supposed to live their life with divine spirits to be free from the disturb of

76 Hanna Widayani, "Pemikiran Seyyed Hossein Nasr Tentang Filsafat Perennial," El-Afkar: Jurnal Pemikiran Keislaman dan Tafsir Hadis 6.1 (2017): 55-60.

77 Azyumardi, "Neo-Sufisme., 295. Danial. "Menghadirkan Tasawuf di Tengah Pluralisme dan Ancaman Radikalisme," Analisis: jurnal studi keislaman 11.1 (2011): 91-108.

${ }^{78}$ Kunawi Basyir, "Makna Eksoteris dan Esoteris Agama dalam Sikap Keberagamaan Eksklusif dan Inklusif," Teosofi: Jurnal Tasawuf dan Pemikiran Islam 8.1 (2018): 218-241.

79 Waryono Abdul Ghafur, etal, Pemikiran Islam., 397. Titin, "Latar Belakang Pemikiran dan Kiprah Seyyed Hossein Nasr," : 132-146.

80 Ubabuddin, "Peran Tasawuf dan Pendidikan Islam Terhadap Akhlak Masyarakat Modern," Jurnal Alwatzikhoebillah: Kajian Islam, Pendidikan, Ekonomi, Humaniora 4.1 (2018): 108-120.

81 Ahmad Sururi., Arqom Kuswanjono, and Agus Himmawan Utomo, Ecological Sufism Concepts In The Thought of Seyyed Hossein Nasr," Research, Society and Development 9.10 (2020): e5769108611-e5769108611. Nasr, Seyyed Hossein, Seyyed Nasr, and Ramin Jahanbegloo. In search of the sacred: A conversation with Seyyed Hossein Nasr on his life and thought. ABC-CLIO, 2010. Kautsar Azhari Noer, "Tasawuf Dalam Peradaban Islam: Apresiasi Dan Kritik," Ulumuna 10.2 (2006): 367-390. Mannan, Audah. "Esensi Tasawuf Akhlaki di Era Modernisasi," Aqidah-Ta: Jurnal Ilmu Aqidah 4.1 (2018): 36-56. Asfa Widiyanto, "The Reception of Seyyed Hossein Nasr's Ideas within the Indonesian Intellectual Landscape," Studia Islamika 23.2 (2016): 193-236. 
materialism and hedonism. This holy spirit will form spiritual power in the human soul so that the connectivity between the servant and God will always be preserved. Finally, humans can be freed from spiritual emptiness. Nasr's neoSufism does not invite humans to leave the world completely and live in seclusion ('uzlah), but remains active in exploring the world and being proactive in social issues and commitments to preserve nature (environment) so that human function as a servant of Allah and His representatives would be well realized.

Seyyed Hossein Nasr's teaching on Sufism puts forward the concept of balance and moderation between the world and the hereafter, shari'ah and haqiqat, individual and social, hablum minallah and hablum minannas and hablum minal alam, spiritual and material. Then, his Sufism teaching is oriented to the divine, insaniyah, and amiyah aspects, which are represented by spirituality (ilahiyah), morality (insaniyah), and social (amiyah), thus giving birth to a pious man with such characaters.

\section{Bibliography}

Abdul Aziz Dahlan (ed), Suplemen Ensiklopedia Islam. Jakarta: Ichtiar Baru Van Hoeve, 1996.

Alaika M. Bagus Kurnia PS, Muhamad Basyrul Muvid, and Risma Savhira DL.

"Sufisme Mahasiswa: Wawasan Kebangsaan Inklusif Berbasis Tasawuf." al-Afkar, Journal For Islamic Studies 4.1 (2021): 123-140.

Alatas, M. Mahdi. "Spiritualitas Dan Modernitas Menurut Pemikiran Seyyed Hossen Nasr (Studi Atas Agama Dan Krisis Kemanusiaan Modern)." Jurnal Akrab Juara 5.2 (2020): 147-160.

Ali, Ibnu. "Nilai-Nilai Dasar Pendidikan Tasawuf Dalam Paradigma Mistik Ibnu 'Arabi Tentang Insan Kamil." El-Furqania:Jurnal Ushuluddin Dan Ilmu-IImu Keislaman 3.01 (2017): 16-37.

Aminudin. "Urgensi Tasawuf Dalam Membangkitkan Kesadaran Spiritual Bagi Masyarakat Modern." Farabi 17.2 (2020): 91-104.

Anas, Moh. "Kritik Hossein Nasr Atas Problem Sains dan Modernitas." Kalam 6.1 (2012): 21-37. 
Andrian, Restu. "Modernisasi Tasawuf Dalam Pengembangan Pendidikan Karakter." Jurnal Mudarrisuna: Media Kajian Pendidikan Agama Islam 9.1 (2019): 36-50.

Annur, Barsihannor. "Sayyed Hossein Nasr (Sufisme Masyarakat Modern)." AlHikmah Journal for Religious Studies 15.2 (2014): 127-134.

Arikunto, Suharsimi. Prosedur Penelitian Sutau Pendekatan Praktis. Jakarta: Rineka Cipta, 2002.

Arista, Mohammad. "Relevansi Ajaran Budha Dan Tasawuf." Putih Jurnal Pengetahuan Tentang Ilmu Dan Hikmah 2.1 (2017): 65-100.

Azra, Azyumardi. "Neo-Sufisme dan Masa Depannya" dalam Muhammad Wahyuni Nafis (ed), Rekontruksi dan Renungan Religius Islam. Jakarta: Paramadina, 1996.

Azra, Azyumardi. "Neo-Sufisme dan Masa Depannya" dalam Muhammad Wahyuni Nafis (ed), Rekontruksi dan Renungan Religius Islam. Jakarta: Paramadina, 1996.

Bakri, Muhammad. "Neo-Sufisme Sebagai Alternatif Dalam Mengatasi Krisis Spritual Modern (Studi Sayeed Hossein)". Skripsi: Universitas Islam Negeri Sultan Syarif Kasim Riau, 2021.

Basyir, Kunawi. "Makna Eksoteris dan Esoteris Agama dalam Sikap Keberagamaan Eksklusif dan Inklusif." Teosofi: Jurnal Tasawuf dan Pemikiran Islam 8.1 (2018): 218-241.

Bistara, Rahabistara. "Tariqah Dimensi Esoteris Dalam Islam (Studi Pemikiran Sayyed Hossein Nasr)." Journal of Islamic Civilization 2.2 (2020): 72-79.

Cholis, Nur, and Syahril Syahril. "Konsep Tasawuf Sebagai Psikoterapi Bagi Problematika Masyarakat Modern (Study Terhadap Kitab Ihya"Ulumiddin Karya Imam Al-Ghazali)." Manthiq 3.1 (2018).

Cohen, L. et.al, Research Method in Education. New York: Routledge, 2011.

Dacholfany, M. Ihsan. "Pendidikan Tasawuf di Pondok Modern darussalam Gontor." Nizham Journal of Islamic Studies 3.2 (2015): 27-42.

Danial. "Menghadirkan Tasawuf di Tengah Pluralisme dan Ancaman Radikalisme." Analisis: jurnal studi keislaman 11.1 (2011): 91-108. 
Encung, Suparman Syukur, and Ilyas Supena. "Insān Kāmil In The Religious Existentialism Philosophy Of Seyyed Hossein Nasr." Hikmatuna 6.1 (2020): 40-50.

Fauhatun, Fathin. "Islam dan Filsafat Perenial: Respon Seyyed Hossein Nasr Terhadap Nestapa Manusia Modern." Jurnal Fuaduna: Jurnal Kajian Keagamaan dan Kemasyarakatan 4.1 (2020): 54-69.

Fuad, Jauhar. "Pendidikan Karakter Dalam Pesantren Tasawuf." Tribakti: Jurnal Pemikiran Keislaman 23.1 (2012).

Gani, A. "Pendidikan Tasawuf Dalam Pembentukan Kecerdasan Spiritual Dan Akhlakul Karimah." Al-Tadzkiyyah: Jurnal Pendidikan Islam 10.2 (2019): 275-286.

Ghafur, Abdul Ghafur, et.al, Pemikiran Islam Kontemporer (Yogyakarta: Jendela, 2003), 391.

Hamzah, Amir. Metode Penelitian Kualitatif. Malang: Literasi Nusantara, 2019.

Harahap, Jaipuri. "Sayyed Hossein Nasr Tentang Filsafat Perennial Dan Human Spiritualitas." Aqlania: Jurnal Filsafat dan Teologi Islam 8.2 (2017): 73-96.

Haryati, Tri Astutik. "Modernitas Dalam Perspektif Seyyed Hossein Nasr." Jurnal Penelitian 8.2 (2012).

Hasan, Ismail. "Tasawuf: Jalan Rumpil Menuju Tuhan." An-Nuha: Jurnal Kajian Islam, Pendidikan, Budaya Dan Sosial 1.1 (2014): 45-63.

Hidayatulloh, Zaki. "Pemahaman Islam Melalui Pendekatan Tasawuf." AtTahdzib: Jurnal Studi Islam dan Muamalah 2.1 (2014): 65-81.

Hidayatulloh, Zaki. "Islam dan Humanisme menurut Seyyed Hossein Nasr". (Tesis: Pascasarjana UIN Sumatera Utara, 2012).

I, Smith, Jane. "Seyyed Hossein Nasr" dalam John L. Esposito (ed), The Oxford Encyclopedia of The Modern Islamic World. New York: Oxford University Press, 1995. Vol. 3.

Imron, Ali. "Tasawuf dan Problem Psikologi Modern." Tribakti: Jurnal Pemikiran Keislaman 29.1 (2018): 23-35. Husen, Achmad, et al. "Pendidikan Karakter Berbasis Spiritualisme Islam (Tasawuf)." Jurnal Studi Al-Qur'an 10.1 (2014): 1-19. 
Irawan, Dedy. "Tasawuf Sebagai Solusi Krisis Manusia Modern: Analisis Pemikiran Seyyed Hossein Nasr." Jurnal Tasfiyah: Jurnal Pemikiran Islam 3.1 (2019).

Irawan, Dedy. "Tasawuf Sebagai Solusi Krisis Manusia Modern: Analisis Pemikiran Seyyed Hossein Nasr." Jurnal Tasfiyah: Jurnal Pemikiran Islam 3.1 (2019).

Khoirudin, Azaki. "Rekonstruksi Metafisika Seyyed Hossein Nasr dan Pendidikan Spiritual." Afkaruna: Indonesian Interdisciplinary Journal of Islamic Studies 10.2 (2014): 202-216.

Khoirudin, Azaki. "Rekonstruksi Metafisika Seyyed Hossein Nasr dan Pendidikan Spiritual." Afkaruna: Indonesian Interdisciplinary Journal of Islamic Studies 10.2 (2014): 202-216.

Lukman. "Tasawuf Dalam Perspektif Sayyed Hossein Nasr." El-Afkar: Jurnal Pemikiran Keislaman dan Tafsir Hadis 8.2 (2019): 25-36.

Lukman. "Tasawuf Dalam Perspektif Sayyed Hossein Nasr." El-Afkar: Jurnal Pemikiran Keislaman dan Tafsir Hadis 8.2 (2019): 25-36.

Mahdi. "Konteks Doktrinal Akhlak Tasawuf Dalam Realitas Sosial." Edueksos: Jurnal Pendidikan Sosial \& Ekonomi 2.2 (2016).

Mahdi. "Urgensi Akhlak Tasawuf dalam Kehidupan Masyarakat Modern." Edueksos: Jurnal Pendidikan Sosial \& Ekonomi 1.1 (2016).

Maisyaroh. "Tasawuf Sebagai Dimensi Batin Ajaran Islam." At-Tafkir 12.2 (2019): 141-151.

Majid, Nurcholis. "Sufisme Baru dan Sufisme Lama: Masalah kontuinitas dan Perkembangan dalam Esoteris Islam" dalam Djohan Effendi (penyunting), Sufisme dan Masa Depan Agama. Jakarta: Pustaka Firdaus, 1993.

Mannan, Audah. "Esensi Tasawuf Akhlaki di Era Modernisasi." Aqidah-Ta: Jurnal Ilmu Aqidah 4.1 (2018): 36-56.

Masduki. "Humanisme Sekuler Versus Humanisme Religius (Kajian Tentang Landasan Filosofis dan Upaya Menemukan Alternatif Melalui Pemikiran Seyyed Hossein Nasr)." Toleransi: Media Ilmiah Komunikasi Umat Beragama 3.1 (2011): 98-118. 
Masykur, Anis Lutfi. “Manusia Menurut Seyyed Hossein Nasr”.(Skripsi: UIN Syarif Hidayatullah Jakarta-Fakultas Ushuluddin dan Filsafat, 2017).

MR, Rifyal Luthfi, and Gunawan Anjar. "Konsep Pendidikan Tasawuf Amali menurut Syaikh Utsman ibn Hasan ibn Ahmad Syakir Al-Khaubawi dalam Kitab Durrah An-Nasihin dan Implementasinya dalam Pembelajaran PAI." Journal Civics \& Social Studies 3.2 (2019): 53-59.

Mu'asyara, Nesia. "Humanisme dalam Perspektif Tasawuf". (Tesis: UIN Raden Intan Lampung, 2019). http://repository.radenintan.ac.id/7603/

Mumtaz, Nadhif Muhammad. "Hakikat Pemikiran Seyyed Hossein Nasr." Jurnal Indo-Islamika 4.2 (2014): 169-178.

Munfarida, Ida. "Relevansi Nilai-Nilai Tasawuf bagi Pengembangan Etika Lingkungan Hidup." Indonesian Journal of Islamic Theology and Philosophy 2.1 (2020): 19-40.

Munjiat, Siti Maryam. "Peran Tasawuf Dalam Pendidikan Karakter." Al-Tarbawi Al-Haditsah: Jurnal Pendidikan Islam 3.2 (2018).

Mustofa, Ali. "Pendidikan Tasawuf Solusi Pembentukan Kecerdasan Spiritual dan Karakter." Inovatif: Jurnal Penelitian Pendidikan, Agama dan Kebudayaan 4.1 (2018): 111-139.

Muvid, Muhamad Basyrul, and Akhmad Fikri Haykal. "Tasawuf Humanistik dan Relevansinya terhadap Kehidupan Sosial Spiritual Masyarakat Post Modern Abad Global (Telaah Atas Pemikiran Tasawuf Said Aqil Siradj dan Muh. Amin Syukur)." Refleksi 19.1 (2020).

Muvid, Muhamad Basyrul. Tasawuf Kontemporer. Jakarta: Amzah, 2020.

Nasr, Seyyed Hossein Nasr, The Heart of Islam, terj. Nurasiah Fakih Sutan Harap. Bandung: Mizan, 2003.

Nasr, Seyyed Hossein, Seyyed Nasr, and Ramin Jahanbegloo. In search of the sacred: A conversation with Seyyed Hossein Nasr on his life and thought. ABC-CLIO, 2010.

Nasr, Seyyed Hossein. Ideals and Realities of Islam (London: George Allen \&Unwin LTD, 1968), 121.

Nasr, Seyyed Hossein. Islam dan Nestapa Manusia Modern, terj. Anas Mahyuddin. Bandung: Pustaka, 1983. 
Nasr, Seyyed Hossein. Islam Tradisi di Tengah Kancah Dunia Modernisme, terj. Luqman Hakim. Bandung: Pustaka, 1987.

Nasr, Seyyed Hossein. Tasawuf Dulu dan Sekarang, terj. Abdul Hadi WM. Jakarta: Pustaka Firdaus, 1994.

Ni'am, Syamsun. "Institusi Pendidikan Dalam Tasawuf." Kanz Philosophia A Journal for Islamic Philosophy and Mysticism 3.2 (2013): 185-200.

Nizar, Moh. Metode Penelitian. Bogor: Ghalia Indonesia, 20005.

Noer, Kautsar Azhari. "Tasawuf Dalam Peradaban Islam: Apresiasi Dan Kritik." Ulumuna 10.2 (2006): 367-390.

Noor, Irfan. "Sufisme Seyyed Hossein Nasr dan Formalisme Agama Di Indonesia." Al-Banjari: Jurnal Ilmiah Ilmu-Ilmu Keislaman 13.2 (2015).

Nurhasanah, Lina. "Peran Tasawuf dalam Kehidupan Manusia Modern (Perspektif Sayyed Hossein Nasr)." El-Afkar: Jurnal Pemikiran Keislaman dan Tafsir Hadis 6.2 (2017).

Nurhidayati, Titin. "Pemikiran Seyyed Hossein Nasr: Konsep Keindahan dan Seni Islami dalam Dunia Pendidikan Islam." Falasifa: Jurnal Studi Keislaman 10.1 (2019): 27-44.

Putra, Andi Eka. "Tasawuf sebagai terapi atas problem spiritual masyarakat modern." Al-Adyan: Jurnal Studi Lintas Agama 8.1 (2013): 45-57.

Putra, Andi Eka. "Tasawuf sebagai terapi atas problem spiritual masyarakat modern." Al-Adyan: Jurnal Studi Lintas Agama 8.1 (2013): 45-57.

Rahman, Fazlur. Islam, terj. Ahsin Mohammad. Bandung: Pustaka, 1994.

Rakhmawati. "Sumbangsih Islam Dalam Menanggulangi Kehampaan Spiritual Masyarakat Modern; Telaah Atas Pemikiran Tasawuf Sayed Husein Nasr." Farabi 11.1 (2014): 66-82.

Rofi, Sofyan, Benny Prasetiya, and Bahar Agus Setiawan. "Pendidikan Karakter Dengan Pendekatan Tasawuf Modern Hamka dan Transformatif Kontemporer." Intiqad: Jurnal Agama dan Pendidikan Islam 11.2 (2019): 396-414.

Rofiq, Muhammad Husnur, and Prastio Surya. "Model Pembentukan Karakter Berbasis Tasawuf Akhlaqi." Ilmuna: Jurnal Studi Pendidikan Agama Islam 1.2 (2019): 65-81. 
Saefulloh, Moh. "Tasawuf sebagai Solusi Alternatif dalam Problematika Modernitas." Islamica: Jurnal Studi Keislaman 2.2 (2008): 207-216.

Sakdullah, Muhammad. "Tasawuf di Era Modrnitas (Kajian Komprehensif Seputar Neo-Sufisme)." Living Islam: Journal of Islamic Discourses 3.2 (2020): 364-386.

Sholikhin, Agus. "Tarekat Sebagai Sistem Pendidikan Tasawuf." Conciencia 18.2 (2018): 1-13.

Sidqi, Ahmad. "Wajah Tasawuf di Era Modern: antara Tantangan dan Jawaban." Epistemé: Jurnal Pengembangan Ilmu Keislaman 10.1 (2015): 128.

Siroj, Said Aqil. Tasawuf sebagai Kritik Sosial. Bandung: Mizan, 2006.

Sodiq, Ahmad. "Konsep Pendidikan Tasawuf (Kajian Tentang Tujuan dan Strategi Pencapaian dalam Pendidikan Tasawuf)." Ijtimaiyya: Jurnal Pengembangan Masyarakat Islam 7.2 (2014): 41-66.

Sukardi, Akhmad. "Dakwah Islam Melalui Ajaran Tasawuf." Al-MUNZIR 8.1 (2018): 1-14.

Sulaiman, Sulaiman. "Perubahan Sosial Berbasis Tasawuf: Studi Kasus Fethullah Gülen dan Gülen Movement." Al-Tahrir: Jurnal Pemikiran Islam 16.1 (2016): 21-46.

Sururi, Ahmad, Arqom Kuswanjono, and Agus Himmawan Utomo. "Ecological Sufism Concepts In The Thought of Seyyed Hossein Nasr." Research, Society and Development 9.10 (2020): e5769108611-e5769108611.

Sutoyo. "Tasawuf Hamka dan rekonstruksi spiritualitas manusia modern." Islamica: Jurnal Studi Keislaman 10.1 (2015): 108-136.

Suwito. "Etika Lingkungan dalam Kosmologi Sufistik Menurut Seyyed Hossein Nasr." Madania: Jurnal Kajian Keislaman 21.2 (2017): 221-234.

Syarif, M. Zainul Hasani. Pendidikan Islam dan Moralitas Sosial: Upaya PreventifKuratif Dekadensi Moral dan Kehampaan Spiritual Manusia Modernis. Prenada Media, 2020.

Thohir, Umar Faruq. "Tasawuf Sebagai Solusi Bagi Problematika Kemodernan: Studi Pemikiran Tasawuf M. Amin Syukur." Jurnal Theologia 24.2 (2013): 43-68. 
Titin, Nurhidayati. "Latar Belakang Pemikiran dan Kiprah Seyyed Hossein Nasr." Falasifa: Jurnal Studi Keislaman 10.2 (2019): 132-146.

Ubabuddin. "Peran Tasawuf dan Pendidikan Islam Terhadap Akhlak Masyarakat Modern." Jurnal Alwatzikhoebillah: Kajian Islam, Pendidikan, Ekonomi, Humaniora 4.1 (2018): 108-120.

Usman, Muhammad Ilham. "Sufisme dan Neo-Sufisme dalam Pusaran Cendikiawan Muslim." Tahdis: Jurnal Kajian Ilmu Al-Hadis 6.2 (2019).

Widayani, Hanna. "Pemikiran Seyyed Hossein Nasr Tentang Filsafat Perennial." El-Afkar: Jurnal Pemikiran Keislaman dan Tafsir Hadis 6.1 (2017): 55-60.

Widiyanto, Asfa. "The Reception of Seyyed Hossein Nasr's Ideas within the Indonesian Intellectual Landscape." Studia Islamika 23.2 (2016): 193-236.

Zahroh, Atssania. "Krisis spiritual manusia modern perspektif Seyyed Hossein Nasr". (Skripsi: UIN Sunan Gunung Djati Bandung, 2020). http://digilib.uinsgd.ac.id/32318/. 
